\title{
Performance and carcass characteristics of Santa Inês pure lambs and crosses with Dorper e Texel at different management systems ${ }^{1}$
}

\author{
Iraides Ferreira Furusho Garcia², Tharcilla Isabella Rodrigues Costa², Amélia Katiane de Almeida², \\ Idalmo Garcia Pereira², Flávio Augusto Pereira Alvarenga ${ }^{2}$, Natália Ludmila Lins Lima ${ }^{2}$ \\ ${ }^{1}$ Financiado pela FAPEMIG (Fundação de Amparo a Pesquisa do Estado de Minas Gerais). \\ 2 Departamento de Zootecnia da Universidade Federal dos Vales do Jequitinhonha e Mucuri.
}

ABSTRACT - It was evaluated the performance and the carcass characteristics of 36 non-castrated male lambs, Santa Inês purebreed and crossbreeds from Dorper $\times$ Santa Inês and Texel $\times$ Santa Inês, managed in three different systems (intensive, semi-intensive and extensive), slaughtered at $38.41 \pm 1.24 \mathrm{~kg}$. It was observed the highest weight gain for lambs reared in intensive system, which also showed the greatest carcass yield. The management systems did not influence carcass measures of animals in intensive system much because of the greater weight of the carcass. The intensive system provided the best performance, regardless the genetic group. The use of Texel and Dorper breeds in crossings with Santa Inês increases carcass yield.

Key Words: crossing, cuts, meat, sheep, weight gain

\section{Desempenho e características de carcaça de cordeiros Santa Inês puros e cruzas com Dorper e Texel em diferentes sistemas de manejo}

\footnotetext{
RESUMO - Avaliaram-se o desempenho e as características de carcaça de 36 cordeiros machos não-castrados, Santa Inês puros e mestiços Dorper $\times$ Santa Inês e Texel $\times$ Santa Inês, manejados em três sistemas (intensivo semi-intensivo e extensivo) e abatidos com peso médio de 38,41 $\pm 1,24 \mathrm{~kg}$. Os melhores ganhos de peso foram observados nos cordeiros criados em sistema intensivo, que apresentaram também os maiores pesos e rendimentos de carcaça. Poucas influências foram constatadas sobre as medidas de carcaça e dos cortes comerciais, sobretudo para maiores pesos nos cortes provenientes do manejo intensivo, proporcionado pelo maior peso da carcaça. O percentual relativo dos cortes em relação à carcaça fria praticamente não variou entre os sistemas. O sistema intensivo proporcionou melhor desempenho, independentemente do grupo genético. A utilização das raças Texel e Dorper em cruzamento com Santa Inês eleva o rendimento das carcaças.
}

Palavras-chave: carne, cortes, cruzamento, ganho de peso, ovinos

\section{Introduction}

The use of crossing can reduce production costs, contributing with increase of uniformity and favoring the marketing of meat (Sherstha \& Fahmy, 2005). Although the option of crossing is an alternative that makes glimpse increment in the ovine livestock, according to Kosgey et al. (2006), it is difficult to propose clear defined criteria due to the differences among the farmers and the circumstances of production in the tropics.

According to Yamamoto et al. (2005), Santa Inês breed has some undesirable characteristics concerning the meat production: slower weight gain and lower quality carcass compared to those of fitted breeds.
Among the breeds fitted for cutting, Texel stands out, mainly in the southern region of the country, particularly because of the precocity and good carcass yield and cuts (Furusho-Garcia et al., 2004). On the other hand, Yamamoto et al. (2005) report that the breed reproducers Dorper and Dorset are more suitable for crossings with Santa Inês sheep, because they provide lambs with better carcass conformation

According to Sainz (1996), the composition and carcass quality are important characteristics to establish crossings of specialized paternal breed for meat with adapted matrices. Thus, the knowledge of the effects of different breeds on the progeny permits to guide the commercial production of ovine meat with the use of crossings. 
Although the practice of crossing increase individual animal performance, and it even improves the productivity of some production systems, one of its biggest restraints is providing appropriate environmental conditions so that the resulting generations from crossings could manifest their genetic potential (Furusho-Garcia \& Pereira, 2007). According to Urano et al. (2006) when considering the high cost of land, confinement is a strategy capable to satisfy both the producer and the consumer once it reduces the production cycle and it brings to market carcasses of young animals and, consequently, of better quality. However, despite of the intensive management being recommended for animals with superior genetics, studies that evaluate crossing products in different management systems are needed.

This work was accomplished with the objective of evaluating the performance and the carcass characteristics and retail cuts of Santa Inês pure lambs and crosses with Dorper and Texel managed in different production systems.

\section{Material e Methods}

The experiment was performed at the Setor de Ovinos of Fazenda Experimental do Moura, of Universidade Federal dos Vales do Jequitinhonha e Mucuri in Curvelo-MG.

It was evaluated 36 non-castrated lambs originated from the mating between Santa Inês females with reproducers from Santa Inês, Texel and Dorper breeds. At birth, the following items were registered: number and weight of the mothers, and weight and sex of the lamb and childbirth type (simple or multiple). Later weightings of the lambs were accomplished to monitor the weight gain. The lambs were weaned at an average body weight of $10 \mathrm{~kg}$. After weaning, they were confined in groups until reaching $15 \mathrm{~kg}$ of body weight, then they were randomly distributed in experimental portions regarded to the management system and genetic group with at least four animals in each portion. From the beginning of the experiment, the weighting of the lambs was weekly performed until they reached the slaughter weight $(38.41 \pm 1.24 \mathrm{~kg})$.

Intensive, semi-intensive, and extensive system were the evaluated systems in this study. In the intensive management, the animals were confined individually and received diet (Table 1 ). In the semi-intensive management, the animals were maintained in aruana grass (Panicum maximum cv Aruana) pastures, with comfortable mineral mixture plus $400 \mathrm{~g}$ of the same concentrate supplied for animals in confinement. The animals in the extensive management were kept only in pasture of aruana grass
(Panicum maximum cv Aruana) plus comfortable mineral mixture.

When they reach the slaughter weight, the animals were fasted for solid diet for aproximately14 hours. The animals were slaughtered by dazing in atlanto-occipital area followed by bleeding. After skinning and evisceration, the hot carcasses were weighed and then cooled in a cold storage chamber for 24 hours $\left( \pm 4^{\circ} \mathrm{C}\right)$. After cooling, the weight of cold carcass and the weight losses due to cooling were calculated. To calculate the yield of hot and cold carcass, the weight of hot and cold carcass in relation to live weight after fasting were used. The biological yield obtained by the empty body weight of each lamb was calculated, in other words, weighing the full and empty gastrointestinal tract full and empty and subtracting their results, the content of digestive tract was obtained. Quantitative characteristics of the carcass such as total length of the carcass (distance from the base of the tail to the base of the neck), thickness of the subcutaneous fat (taken between the $12^{\text {th }}$ and $13^{\text {th }}$ rib), croup width (maximum width among the trochanters of both femurs), croup perimeter (perimeter of this area, referenced by the trochanters of both femurs) were measured according to methodology by Fisher \& Boer (1994). After those measurements, the carcass was longitudinally divided into two equal parts and internal length (maximum distance between the previous edge of the ischium-pubic symphysis and the previous edge of the 1st rib), leg length (distance between the fibula and the previous edge of the tarsalmetatarsal joint), and the thorax depth (maximum width between the sternum and back) were measured on the left half-carcass according to Fisher \& Boer (1994).

Tail, kidneys and perirenal and cavity fats were removed and next the left half-carcass was subdivided into leg, loin, shoulder, chop, rib/belly, anterior arm, posterior arm and neck, as described by (Furusho-Garcia et al., 2004), which

Table 1 - Ingredients composition and nutrients of the experimental diet

\begin{tabular}{lc}
\hline Ingredient & $(\%)$ \\
\hline Tifton hay (Cynodon dactylus) & 30.0 \\
Ground corn & 51.6 \\
Soy bran & 16.5 \\
Mineral/vitaminic premix & 1.0 \\
Limestone & 0.9 \\
Nutrient ${ }^{1}$ & \\
Crude protein & $14.34 \%$ \\
Metabolizable energy & $2557 \mathrm{kcal} / \mathrm{kg}$ \\
Calcium & $0.51 \%$ \\
Phosphorus & $0.28 \%$ \\
Ether extract & $2.90 \%$ \\
\hline 1 Calculated according to ingredients composition of NRC Table $(2006)$.
\end{tabular}

R. Bras. Zootec., v.39, n.6, p.1313-1321, 2010 
were then weighed and the proportions of the cuts regarded to the cold carcass weight were determined.

The data were analyzed using SAS program (SAS, 1991) by the GLM procedure. The experimental design was complete randomized in a $3 \times 3$ factorial scheme (three genetic groups and three management systems), with four repetitions by management system. Two portions were considered lost because the animals have remarkable pattern differences in the respective management system. Thus, the total analyzed data were 34, with two management systems with three repetitions and the remaining with four repetitions. The adjusted means were compared by Student's t Test at $5 \%$ of significance.

\section{Results and Discussion}

During the experiment period, significant interactions between total weight gain and daily weight gain were not observed among management system and genetic group (Table 2). It was noted that the animals in intensive system needed less time to reach slaughter weight than those reared in semi-intensive and extensive system. This result was already expected, because the animals in intensive system received a diet with $70 \%$ concentrated, therefore more energetic, whereas in the semi-intensive system, part of the diet was the pasture, and in the extensive system, the animals had only the pasture as feeding source. Medeiros et al. (2008),when analyzing the concentrate levels in the diet of Morada Nova breed lambs in confinement, observed that the period of permanence of animals in confinement decreased linearly as larger amount of concentrate was offered in diet, anticipating the age at slaughter.
As for the daily weight gain, the animals of intensive management were superior to the semi-intensive and extensive management (Table 2). This is because of the balanced diet supplied to the animals in intensive management, and for the animals of semi-intensive and extensive systems, kept full time with access to pasture, that was caused by adverse weather conditions during the dry or rain seasons causing variations over the experimental period. The results obtained in the present study are in agreement with Carvalho et al. (2007) who observed a linear reduction in weight gain of the lambs when there was an increase of bulky concentration and the proportion of concentrate in the diet decreased.

For experiment period and weight gain, differences were not observed among the genetic groups. These results evidence the potential of Santa Inês breed for meat production, when compared to mixed genotypes whose paternal breed are fitted for cutting.

There was not significant interaction between genetic group and management system for pre-slaughter weights (before fasting), slaughter, digesting content and of empty body, as well as for the percentage of weight loss during fasting (Table 3$)$. There was no effect $(\mathrm{P}>0.05)$ of genetic group on pre-slaughter weight and slaughter weight either, which was reinforced by the fact that neither was there any effects on weight loss during fasting, both in weight and in percentage. However, the management system affected the losses that occured during fasting, although it did not influence the pre-slaughter and slaughter weights. The animals finished in semi-intensive system presented higher losses during fasting, when compared to the intensive system. The animals in systems where the bulky

Table 2 - Means of experiment period, total and daily weight gain of lambs in function of genotype and management system

\begin{tabular}{|c|c|c|c|c|c|}
\hline \multirow[t]{2}{*}{ Genetic group } & \multicolumn{3}{|c|}{ Management } & \multirow[b]{2}{*}{ Mean } & \multirow[b]{2}{*}{$\mathrm{SME}^{1}$} \\
\hline & Extensive & Semi-intensive & Intensive & & \\
\hline \multicolumn{6}{|c|}{ Experiment period (days) } \\
\hline $1 / 2$ Dorper $+1 / 2$ Santa Inês & 235 & 201 & 104 & 180 & 9.67 \\
\hline $1 / 2$ Texel $+1 / 2$ Santa Inês & 259 & 214 & 104 & 192 & 10.20 \\
\hline Pure Santa Inês & 228 & 206 & 130 & 188 & 9.67 \\
\hline Mean & $241 c$ & $207 b$ & $113 a$ & 185 & \\
\hline \multicolumn{6}{|c|}{ Total weight gain (kg) } \\
\hline $1 / 2$ Dorper $+1 / 2$ Santa Inês & 19.40 & 21.45 & 21.19 & 20.68 & 0.56 \\
\hline $1 / 2$ Texel $+1 / 2$ Santa Inês & 21.37 & 23.32 & 21.60 & 22.10 & 0.59 \\
\hline Pure Santa Inês & 19.40 & 21.15 & 23.50 & 21.35 & 0.56 \\
\hline Mean & $20.05 a$ & $21.97 \mathrm{a}$ & $22.10 \mathrm{a}$ & 21.38 & \\
\hline \multicolumn{6}{|c|}{ Daily weight gain (kg/day) } \\
\hline $1 / 2$ Dorper $+1 / 2$ Santa Inês & 0.083 & 0.107 & 0.214 & 0.135 & 0.01 \\
\hline $1 / 2$ Texel $+1 / 2$ Santa Inês & 0.083 & 0.111 & 0.210 & 0.135 & 0.01 \\
\hline Pure Santa Inês & 0.085 & 0.107 & 0.194 & 0.129 & 0.01 \\
\hline Mean & $0.084 b$ & $0.109 \mathrm{~b}$ & $0.206 \mathrm{a}$ & 0.134 & \\
\hline
\end{tabular}

Means followed by different letters, capital letter in line and small letters in columns, differ $(\mathrm{P}<0.05)$ by $\mathrm{t}$ test.

${ }^{1}$ Standard mean error. 
consumption is higher, the rate of passage in the rumen can be lower and, consequently, from the moment that fasting begins until slaughter, it will probably lead larger amounts of food, mainly in the rumen, to be eliminated when compared to animals in intensive systems. In addition, in semi-intensive system with the offer of $400 \mathrm{~g} /$ day of concentrated, it might have stimulated larger consumption of pasture, since the offered concentrate might have increased, in a certain way, the degradation rate of the foods, which increases the consumption. Although that difference occured for weight loss in fasting, it was not enough to change slaughter weights because it was a small loss in absolute value.

For the weight of the digestive content, it was observed a difference among the genetic groups (Table 3), in which animals from the crossing Texel $\times$ Santa Inês and Dorper $\times$ Santa Inês obtained smaller values compared to Santa Inês pure lambs. That can be linked to the incorporation of genes from adapted exotic breed that have smaller digesting compartments than the native breed. The digestive content determines the calculation for empty body weight and, in this case, despite of the differences in weight and content proportion between Dorper $\times$ Santa Inês and pure Santa Inês, these two genetic groups did not present differences in the empty body weight. However, the Texel $\times$ Santa Inês lambs obtained an empty body weight higher than pure Santa Inês, indicating a productive superiority when the option to use the reproducer of the Texel breed in crossing with Santa Inês matrices, what does not happen for the Dorper breed, when the production of animal is evaluated on body weight. However it is necessary to consider other aspects such as those regarded to the carcass.

It was verified that animals reared in intensive system presented higher empty body weights (Table 3), as a response from the smallest weights and proportion of gastrointestinal contents. Similar results were observed by Carvalho et al. (2007) who evaluated lambs in confinement or with supplementation in native field. The smaller proportion of digestive content in confined animals is explained by the diet composed mainly of non-bulky foods, which are more quickly degraded in the rumen.

There were no significant interactions between management system and genetic group for weights and carcass yield (Table 4). Weights of hot and cold carcass were larger for animals raised in intensive system, showing that this system provided a more digestible diet, making more nutrients available for development of the main tissues which compose the carcass (muscle, bone and fat), compared to other body components. Despite that management system

Table 3 - Means of live and empty weight, losses in fasting and digestive content of lambs in function of the genotype and management system

\begin{tabular}{|c|c|c|c|c|c|}
\hline \multirow[t]{2}{*}{ Genetic group } & \multicolumn{3}{|c|}{ Management } & \multirow[b]{2}{*}{ Mean } & \multirow[b]{2}{*}{$\mathrm{SME}^{1}$} \\
\hline & Extensive & Semi-intensive & Intensive & & \\
\hline \multicolumn{6}{|c|}{ Pre-slaughter weight (kg) } \\
\hline $1 / 2$ Dorper $+1 / 2$ Santa Inês & 38.10 & 38.67 & 38.30 & $38.40 \mathrm{~A}$ & 0.38 \\
\hline $1 / 2$ Texel $+1 / 2$ Santa Inês & 37.90 & 38.47 & 38.95 & $38.44 \mathrm{~A}$ & 0.38 \\
\hline Pure Santa Inês & 37.40 & 38.90 & 38.72 & $38.34 \mathrm{~A}$ & 0.36 \\
\hline Mean & $37.85 \mathrm{a}$ & $38.68 \mathrm{a}$ & $38.65 a$ & 38.41 & \\
\hline \multicolumn{6}{|c|}{ Slaughter weight (kg) } \\
\hline $1 / 2$ Dorper $+1 / 2$ Santa Inês & 35.10 & 34.75 & 36.33 & $35.39 \mathrm{~A}$ & 0.49 \\
\hline $1 / 2$ Texel + 1/2 Santa Inês & 35.16 & 34.95 & 36.67 & $35.59 \mathrm{~A}$ & 0.49 \\
\hline Pure Santa Inês & 34.72 & 35.97 & 36.67 & $35.79 \mathrm{~A}$ & 0.47 \\
\hline Mean & $34.99 a$ & $35.22 \mathrm{a}$ & $36.56 a$ & 35.58 & \\
\hline \multicolumn{6}{|c|}{ Weight loss in fasting (\%) } \\
\hline $1 / 2$ Dorper $+1 / 2$ Santa Inês & 8.16 & 10.10 & 5.20 & $7.84 \mathrm{~A}$ & 0.92 \\
\hline $1 / 2$ Texel + 1/2 Santa Inês & 7.21 & 9.19 & 5.84 & $7.42 \mathrm{~A}$ & 0.92 \\
\hline Pure Santa Inês & 7.14 & 7.46 & 5.33 & $6.64 \mathrm{~A}$ & 0.87 \\
\hline Mean & $7.52 \mathrm{ab}$ & $8.92 \mathrm{a}$ & $5.46 \mathrm{~b}$ & 7.30 & \\
\hline \multicolumn{6}{|c|}{ Digestive content weight (kg) } \\
\hline $1 / 2$ Dorper $+1 / 2$ Santa Inês & 6.84 & 6.02 & 4.92 & $5.93 \mathrm{~B}$ & 0.37 \\
\hline $1 / 2$ Texel + 1/2 Santa Inês & 6.07 & 5.41 & 4.50 & $5.33 \mathrm{~B}$ & 0.37 \\
\hline Pure Santa Inês & 8.34 & 8.28 & 4.93 & $7.19 \mathrm{~A}$ & 0.35 \\
\hline Mean & $7.08 \mathrm{a}$ & $6.57 \mathrm{a}$ & $4.78 \mathrm{~b}$ & 6.15 & \\
\hline \multicolumn{6}{|c|}{ Empty body weight (kg) } \\
\hline $1 / 2$ Dorper $+1 / 2$ Santa Inês & 28.26 & 28.73 & 31.41 & $29.47 \mathrm{AB}$ & 0.49 \\
\hline $1 / 2$ Texel $+1 / 2$ Santa Inês & 29.10 & 29.54 & 32.17 & $30.27 \mathrm{~A}$ & 0.49 \\
\hline Pure Santa Inês & 26.38 & 27.69 & 31.74 & $28.60 \mathrm{~B}$ & 0.46 \\
\hline Mean & $27.91 \mathrm{~b}$ & $28.65 b$ & $31.78 \mathrm{a}$ & 29.45 & \\
\hline
\end{tabular}

Means followed by different letters, capital letter in line and small letters in columns, differ $(\mathrm{P}<0.05)$ by $\mathrm{t}$ test.

${ }^{1}$ Standard mean error. 
provides heavier carcasses, there is no way to affirm that the other body components that do not compose the carcass were in smaller proportion, because the body empty weight for those confined animals was also larger.

There was no effect of the genetic group on the hot and cold carcass weights (Table 4), indicating that pure Santa Inês breed is equaled to F1 animals derived from crosses with the fitted breed Texel and Dorper. The results found in the present work corroborate with Villarroel et al. (2006) who did not observe any differences in hot and cold carcasses weights of Texel and Santa Inês mixed lambs, slaughtered at the age of eight months.

The loss by cooling the carcass was not affected by the genetic group, but it was influenced by the management system (Table 4). It was observed that the animals reared in intensive system obtained higher losses. The highest weight is explained by the fact of the own carcasses being heavier. However, the higher percentage presented in confinement was not expected, because according to Furusho-Garcia et al. (2004), animals with larger fat coverage, which is provided by a more intensive management, have a protection against losses of liquids during the cooling. The values found might have suffered environment interference, probably variations in the temperature of the cold storage chamber.

The carcass yield was influenced both by the genetic group and by the management system (Table 4). Both for the hot as cold carcass yield, the Santa Inês pure animals presented lower proportions when compared to the other crossings, except for cold carcass yield when the F1 Dorper animals were similar to Santa Inês. Animals from the crossing of reproductive Dorper presented yield similar to those from the crossing of reproductive Texel, both in evaluation of the hot and cold carcass. For biological yield, effect $(\mathrm{P}<0.05)$ of the genetic group was not observed, indicating that the differences observed for digestive contents interfered in values obtained for that yield.

The animals intensively managed presented larger yield of hot and cold carcass (Table 4), compared to lambs reared in extensive and semi-intensive systems, probably due to the diet with larger nutrient contribution. That result is in agreement with that of Silva Sobrinho (2001), who mentions feeding and management as factors that can affect the

Table 4 - Weights and medium carcass yield of Santa Inês pure lambs and crossed lambs under different management systems and their respective standard errors

\begin{tabular}{|c|c|c|c|c|c|}
\hline \multirow[b]{2}{*}{ Genetic group } & \multicolumn{3}{|c|}{ Management } & \multirow[b]{2}{*}{ Mean } & \multirow[b]{2}{*}{$\mathrm{SME}^{1}$} \\
\hline & Extensive & Semi-intensive & Intensive & & \\
\hline \multicolumn{6}{|c|}{ Hot carcass weight (kg) } \\
\hline $1 / 2$ Dorper $1 / 2$ Santa Inês & 15.02 & 14.85 & 17.13 & $15.66 \mathrm{~A}$ & 0.32 \\
\hline $1 / 2$ Texel $\times 1 / 2$ Santa Inês & 15.16 & 14.86 & 17.72 & $15.91 \mathrm{~A}$ & 0.32 \\
\hline Pure Santa Inês & 13.75 & 14.17 & 17.62 & $15.18 \mathrm{~A}$ & 0.30 \\
\hline Mean & $14.64 b$ & $14.62 b$ & $17.49 \mathrm{a}$ & 15.55 & \\
\hline \multicolumn{6}{|c|}{ Cold carcass weight (kg) } \\
\hline $1 / 2$ Dorper $+1 / 2$ Santa Inês & 14.44 & 14.50 & 16.50 & $15.14 \mathrm{~A}$ & 0.31 \\
\hline $1 / 2$ Texel + 1/2 Santa Inês & 14,80 & 14.78 & 17.22 & $15.60 \mathrm{~A}$ & 0.31 \\
\hline Pure Santa Inês & 13.42 & 14.10 & 16.95 & $14.82 \mathrm{~A}$ & 0.30 \\
\hline Mean & $14.22 b$ & $14.46 \mathrm{~b}$ & $16.89 a$ & 15.16 & \\
\hline \multicolumn{6}{|c|}{ Loss by cooling (\%) } \\
\hline $1 / 2$ Dorper + $1 / 2$ Santa Inês & 3.79 & 2.32 & 3.65 & $3.25 \mathrm{~A}$ & 0.58 \\
\hline $1 / 2$ Texel $+1 / 2$ Santa Inês & 2.39 & 0.53 & 2.85 & $1.92 \mathrm{~A}$ & 0.58 \\
\hline Pure Santa Inês & 2.36 & 0.52 & 3.85 & $2.25 \mathrm{~A}$ & 0.54 \\
\hline Mean & $2.85 \mathrm{a}$ & $1.13 \mathrm{a}$ & $3.45 \mathrm{a}$ & 2.47 & \\
\hline \multicolumn{6}{|c|}{ Hot carcass yield (\%) } \\
\hline $1 / 2$ Dorper $+1 / 2$ Santa Inês & 42.85 & 42.72 & 47.16 & $44.24 \mathrm{~A}$ & 0.67 \\
\hline $1 / 2$ Texel $+1 / 2$ Santa Inês & 43.16 & 42.47 & 48.31 & $44.65 \mathrm{~A}$ & 0.67 \\
\hline Pure Santa Inês & 39.65 & 39.46 & 47.97 & $42.36 \mathrm{~B}$ & 0.63 \\
\hline Mean & $41.89 \mathrm{~b}$ & $41.55 b$ & $47.81 \mathrm{a}$ & 43.67 & \\
\hline \multicolumn{6}{|c|}{ Cold carcass yield - commercial (\%) } \\
\hline $1 / 2$ Dorper $+1 / 2$ Santa Inês & 41.22 & 41.72 & 45.44 & $42.79 \mathrm{AB}$ & 0.68 \\
\hline $1 / 2$ Texel $+1 / 2$ Santa Inês & 42.11 & 42.25 & 46.94 & $43.77 \mathrm{~A}$ & 0.68 \\
\hline Pure Santa Inês & 38.72 & 39.25 & 46.13 & $41.36 \mathrm{~B}$ & 0.65 \\
\hline Mean & $40.68 b$ & $41.07 \mathrm{~b}$ & $46.17 \mathrm{a}$ & 42.57 & \\
\hline \multicolumn{6}{|c|}{ Biological yield (\%) } \\
\hline $1 / 2$ Dorper $+1 / 2$ Santa Inês & 51.26 & 50.58 & 52.55 & $51.47 \mathrm{~A}$ & 0.76 \\
\hline $1 / 2$ Texel $+1 / 2$ Santa Inês & 50.87 & 50.01 & 53.53 & $51.47 \mathrm{~A}$ & 0.76 \\
\hline Pure Santa Inês & 50.92 & 50.91 & 53.30 & $51.71 \mathrm{~A}$ & 0.72 \\
\hline Mean & $51.02 \mathrm{ab}$ & $50.50 \mathrm{~b}$ & $53.13 \mathrm{a}$ & 51.54 & \\
\hline
\end{tabular}

Means followed by different letters, capital letter in line and small letters in columns, differ $(\mathrm{P}<0.05)$ by $\mathrm{t}$ test.

${ }^{1}$ Standard mean error. 
carcass yield of lambs. Carvalho et al. (2007) verified that the hot carcass yield decreased linearly as the bulky content in diets increased. Therefore, Geay (1975) affirms that the carcass yield based on body weight of the animals are affected, among other factors, by the type of the diet.

Significant interactions were not observed between management system and genetic group for carcass measures (Table 5). The management system did not influence the evaluated carcass measures, except the thickness of subcutaneous fat which was higher for animals reared in intensive system, compared to animals in extensive management. That result was expected in function of the high quality nutrition for the confined, which favored the deposition of subcutaneous fat.

The genetic group affected the leg length, internal length of the carcass and the croup circumference (Table 5). Santa Inês pure lambs obtained higher measures for these parameters, and for croup circumference, it was expected that the crossed lambs would have higher values because of overcoming genetic influence for meat production, which did not happen, indicating that in crossing with Santa Inês breed, the products can lose that characteristic.

Except for the percentage of the neck in relation to cold carcass, significant interaction was not observed between management system and genetic group for the weights and percentages of the evaluated cuts (Tables 6 and 7).

There was no significant difference among the three genetic groups for weight of retail cuts (Table 6), however the genetic group affected the percentages (\%) of the posterior arm, carré and neck (Table 7). There was superiority of Santa Inês pure lambs on F1 Dorper $\times$ Santa Inês for posterior arm and carré, explained by the larger size of Santa Inês breed in relation to Dorper breed, and the F1 lambs Texel $\times$ Santa Inês, obtained for carré similar percentage to pure Santa Inês and superior to F1 Dorper $\times$ Santa Inês. Regarding the neck percentage, it was observed that the F1

Table 5 - Measures of Santa Inês pure lambs carcass and crosses with Dorper and Texel in different management systems

\begin{tabular}{|c|c|c|c|c|c|}
\hline \multirow[b]{2}{*}{ Genetic group } & \multicolumn{3}{|c|}{ Management } & \multirow[b]{2}{*}{ Mean } & \multirow[b]{2}{*}{$\mathrm{SME}^{1}$} \\
\hline & Extensive & Semi-intensive & Intensive & & \\
\hline \multicolumn{6}{|c|}{ Total length of carcass $(\mathrm{cm})$} \\
\hline $1 / 2$ Dorper + 1/2 Santa Inês & 46.75 & 46.55 & 47.50 & 46.93A & 0.86 \\
\hline $1 / 2$ Texel $+1 / 2$ Santa Inês & 44.30 & 47.15 & 47.67 & $46.37 \mathrm{~A}$ & 0.86 \\
\hline Pure Santa Inês & 50.02 & 46.07 & 47.67 & $47.92 \mathrm{~A}$ & 0.81 \\
\hline Mean & $47.02 \mathrm{a}$ & $46.59 \mathrm{a}$ & $47.62 \mathrm{a}$ & 47.08 & \\
\hline \multicolumn{6}{|c|}{ Leg length (cm) } \\
\hline $1 / 2$ Dorper $+1 / 2$ Santa Inês & 24.95 & 23.52 & 23.50 & 23.99B & 0.57 \\
\hline $1 / 2$ Texel + 1/2 Santa Inês & 24.43 & 24.82 & 25.90 & $25.05 \mathrm{AB}$ & 0.57 \\
\hline Pure Santa Inês & 25.72 & 26.22 & 25.90 & $25.95 \mathrm{~A}$ & 0.54 \\
\hline Mean & $25.04 \mathrm{a}$ & $24.86 a$ & $25.10 \mathrm{a}$ & 25.00 & \\
\hline \multicolumn{6}{|c|}{ Croup width (cm) } \\
\hline $1 / 2$ Dorper + $1 / 2$ Santa Inês & 21.62 & 21.05 & 20.87 & $21.18 \mathrm{~A}$ & 0.55 \\
\hline $1 / 2$ Texel $+1 / 2$ Santa Inês & 23.03 & 21.05 & 21.55 & $21.88 \mathrm{~A}$ & 0.55 \\
\hline Pure Santa Inês & 20.32 & 21.47 & 24.17 & $21.99 \mathrm{~A}$ & 0.53 \\
\hline Mean & $21.66 \mathrm{a}$ & $21.19 a$ & $22.20 \mathrm{a}$ & 21.68 & \\
\hline \multicolumn{6}{|c|}{ Thorax depth (cm) } \\
\hline $1 / 2$ Dorper $+1 / 2$ Santa Inês & 27.20 & 26.70 & 26.87 & $26.92 \mathrm{~A}$ & 0.46 \\
\hline $1 / 2$ Texel $+1 / 2$ Santa Inês & 26.40 & 28.27 & 27.10 & $27.26 \mathrm{~A}$ & 0.46 \\
\hline Pure Santa Inês & 27.65 & 24.97 & 27.45 & $26.69 \mathrm{~A}$ & 0.44 \\
\hline Mean & $27.08 \mathrm{a}$ & $26.65 a$ & $27.14 \mathrm{a}$ & 26.96 & \\
\hline \multicolumn{6}{|c|}{ Internal length (cm) } \\
\hline $1 / 2$ Dorper $+1 / 2$ Santa Inês & 61.75 & 66.50 & 62.50 & $63.58 \mathrm{~A}$ & 0.78 \\
\hline $1 / 2$ Texel + 1/2 Santa Inês & 60.87 & 62.50 & 60.57 & $61.31 \mathrm{~B}$ & 0.78 \\
\hline Pure Santa Inês & 64.07 & 63.75 & 64.17 & $64.00 \mathrm{~A}$ & 0.74 \\
\hline Mean & $62.23 a$ & $64.25 \mathrm{a}$ & $62.42 \mathrm{a}$ & 62.96 & \\
\hline \multicolumn{6}{|c|}{ Croup circumference $(\mathrm{cm})$} \\
\hline $1 / 2$ Dorper $+1 / 2$ Santa Inês & 60.02 & 58.85 & 60.23 & $59.70 \mathrm{~B}$ & 0.85 \\
\hline $1 / 2$ Texel $+1 / 2$ Santa Inês & 61.93 & 59.40 & 60.70 & $60.68 \mathrm{~B}$ & 0.85 \\
\hline Pure Santa Inês & 60.50 & 65.55 & 64.12 & $63.39 \mathrm{~A}$ & 0.80 \\
\hline Mean & $60.82 \mathrm{a}$ & $61.27 \mathrm{a}$ & $61.69 a$ & 61.25 & \\
\hline \multicolumn{6}{|c|}{ Subcutaneous fat (mm) } \\
\hline $1 / 2$ Dorper $+1 / 2$ Santa Inês & 0.76 & 0.81 & 2.68 & $1.42 \mathrm{~A}$ & 0.24 \\
\hline $1 / 2$ Texel $+1 / 2$ Santa Inês & 0.70 & 1.27 & 0.99 & $0.99 \mathrm{~A}$ & 0.24 \\
\hline Pure Santa Inês & 0.65 & 1.25 & 1.43 & $1.11 \mathrm{~A}$ & 0.22 \\
\hline Mean & $0.70 \mathrm{~b}$ & $1.11 \mathrm{ab}$ & $1.70 \mathrm{a}$ & 1.17 & \\
\hline
\end{tabular}

Means followed by different letters, capital letter in line and small letters in columns, differ $(\mathrm{P}<0.05)$ by $\mathrm{t}$ test.

1 Standard mean error. 
lambs Texel $\times$ Santa Inês presented lower values in relation to the other two evaluated genetic groups, which can be explaned by the fact that the body conformation of Texel breed present compact neck and smaller length.

The different management systems affected the weights of retail cuts (Table 6). The weights of the shoulder, leg, loin, carré and rib/belly of lambs reared in intensive system were higher when compared to lambs in semiintensive and extensive systems. This can be a response to the increase in the level of metabolizable energy consumed by animals, in the three respective production systems, which is corroborated by Alves et al. (2003), who reported increasing linear effect for shoulder weight and superior rib of Santa Inês ovines, as the levels of metabolizable energy in the diet increased.
In the evaluation of percentage of the cuts regarded to cold carcass weight (Table 7), significant differences were not observed $(\mathrm{P}>0.05)$ among the management systems, except for the smallest mean percentage of the previous arm (1.52\%), observed in animals of the intensive management. This happens because animals in semi-intensive and extensive management system requires more musculature effort from the previous arm than the animals in confinement, which present restricted circulation.

The results found in the present work are in agreement with those by Carvalho et al. (2005) who evaluated undefined breed lambs in confinement, supplemented in native field and "creep-feeding", and they observed in the values little variability for fourth proportions, shoulder, side cut rib and neck among the tested feeding systems.

Table 6 - Weight $(\mathrm{kg})$ of carcasses cuts of Santa Inês pure lambs and crosses with Dorper and Texel in different management systems

\begin{tabular}{|c|c|c|c|c|c|}
\hline \multirow[b]{2}{*}{ Genetic group } & \multicolumn{3}{|c|}{ Management } & \multirow[b]{2}{*}{ Mean } & \multirow[b]{2}{*}{$\mathrm{SME}^{1}$} \\
\hline & Extensive & Semi-intensive & Intensive & & \\
\hline \multicolumn{6}{|c|}{ Weight of posterior arm } \\
\hline $1 / 2$ Dorper $+1 / 2$ Santa Inês & 0.30 & 0.30 & 0.32 & $0.31 \mathrm{~A}$ & 0.01 \\
\hline 1/2 Texel + 1/2 Santa Inês & 0.32 & 0.31 & 0.34 & $0.32 \mathrm{~A}$ & 0.01 \\
\hline Pure Santa Inês & 0.31 & 0.34 & 0.34 & $0.33 \mathrm{~A}$ & 0.01 \\
\hline Mean & $0.31 \mathrm{a}$ & $0.31 \mathrm{a}$ & $0.34 \mathrm{a}$ & 0.32 & \\
\hline \multicolumn{6}{|c|}{ Weight of anterior arm } \\
\hline $1 / 2$ Dorper $+1 / 2$ Santa Inês & 0.25 & 0.25 & 0.25 & $0.25 \mathrm{~A}$ & 0.01 \\
\hline $1 / 2$ Texel $+1 / 2$ Santa Inês & 0.24 & 0.24 & 0.24 & $0.24 \mathrm{~A}$ & 0.01 \\
\hline Pure Santa Inês & 0.24 & 0.24 & 0.28 & $0.25 \mathrm{~A}$ & 0.01 \\
\hline Mean & $0.24 \mathrm{a}$ & $0.24 \mathrm{a}$ & $0.26 \mathrm{a}$ & 0.25 & \\
\hline \multicolumn{6}{|c|}{ Shoulder weight } \\
\hline $1 / 2$ Dorper $+1 / 2$ Santa Inês & 1.14 & 1.03 & 1.26 & $1.14 \mathrm{~A}$ & 0.04 \\
\hline $1 / 2$ Texel + 1/2 Santa Inês & 1.12 & 1.15 & 1.34 & $1.20 \mathrm{~A}$ & 0.04 \\
\hline Pure Santa Inês & 1.04 & 1.04 & 1.25 & $1.11 \mathrm{~A}$ & 0.03 \\
\hline Mean & $1.10 \mathrm{~b}$ & $1.07 \mathrm{~b}$ & $1.28 \mathrm{a}$ & 1.15 & \\
\hline \multicolumn{6}{|c|}{ Leg weight } \\
\hline $1 / 2$ Dorper $+1 / 2$ Santa Inês & 2.03 & 2.01 & 2.22 & $2.09 \mathrm{~A}$ & 0.04 \\
\hline 1/2 Texel + 1/2 Santa Inês & 2.09 & 2.00 & 2.36 & $2.15 \mathrm{~A}$ & 0.04 \\
\hline Pure Santa Inês & 1.85 & 1.92 & 2.27 & $2.01 \mathrm{~A}$ & 0.04 \\
\hline Mean & $1.99 b$ & $1.98 \mathrm{~b}$ & $2.28 \mathrm{a}$ & 2.08 & \\
\hline \multicolumn{6}{|c|}{ Loin weight } \\
\hline $1 / 2$ Dorper $+1 / 2$ Santa Inês & 0.49 & 0.44 & 0.58 & $0.50 \mathrm{~A}$ & 0.02 \\
\hline $1 / 2$ Texel $+1 / 2$ Santa Inês & 0.46 & 0.52 & 0.62 & $0.53 \mathrm{~A}$ & 0.02 \\
\hline Pure Santa Inês & 0.47 & 0.45 & 0.61 & $0.51 \mathrm{~A}$ & 0.02 \\
\hline Mean & $0.47 \mathrm{~b}$ & $0.47 \mathrm{~b}$ & $0.60 \mathrm{a}$ & 0.52 & \\
\hline \multicolumn{6}{|c|}{ Carré weight } \\
\hline $1 / 2$ Dorper $+1 / 2$ Santa Inês & 0.89 & 0.98 & 1.20 & $1.02 \mathrm{~A}$ & 0.04 \\
\hline $1 / 2$ Texel $+1 / 2$ Santa Inês & 1.14 & 1.11 & 1.27 & $1.17 \mathrm{~A}$ & 0.04 \\
\hline Pure Santa Inês & 1.02 & 1.00 & 1.34 & $1.12 \mathrm{~A}$ & 0.04 \\
\hline Mean & $1.02 \mathrm{~b}$ & $1.03 \mathrm{~b}$ & $1.27 \mathrm{a}$ & 1.10 & \\
\hline \multicolumn{6}{|c|}{ Rib/Belly weight } \\
\hline $1 / 2$ Dorper + 1/2 Santa Inês & 1.10 & 1.27 & 1.52 & $1.30 \mathrm{~A}$ & 0,06 \\
\hline $1 / 2$ Texel $+1 / 2$ Santa Inês & 1.29 & 1.19 & 1.54 & $1.34 \mathrm{~A}$ & 0.06 \\
\hline Pure Santa Inês & 1.15 & 1.17 & 1.58 & $1.30 \mathrm{~A}$ & 0.06 \\
\hline Mean & $1.18 \mathrm{~b}$ & $1.21 b$ & $1.55 \mathrm{a}$ & 1.31 & \\
\hline \multicolumn{6}{|c|}{ Neck weight } \\
\hline $1 / 2$ Dorper $+1 / 2$ Santa Inês & 1.23 & 1.15 & 1.36 & $1.25 \mathrm{~A}$ & 0.07 \\
\hline $1 / 2$ Texel $+1 / 2$ Santa Inês & 0.95 & 1.13 & 1.12 & $1.07 \mathrm{~A}$ & 0.07 \\
\hline Pure Santa Inês & 1.35 & 1.21 & 1.17 & $1.24 \mathrm{~A}$ & 0.06 \\
\hline Mean & $1.17 \mathrm{a}$ & $1.16 \mathrm{a}$ & $1.22 \mathrm{a}$ & 1.19 & \\
\hline
\end{tabular}

Means followed by different letters, capital letter in line and small letters in columns, differ $(\mathrm{P}<0.05)$ by $\mathrm{t}$ test.

${ }^{1}$ Standard mean error. 
Table 7 - Percentage (\%) of carcass cuts of Santa Inês pure lambs and crosses with Dorper and Texel in different management systems

\begin{tabular}{|c|c|c|c|c|c|}
\hline \multirow[b]{2}{*}{ Genetic group } & \multicolumn{3}{|c|}{ Management } & \multirow[b]{2}{*}{ Mean } & \multirow[b]{2}{*}{$\mathrm{SME}^{1}$} \\
\hline & Extensive & Semi-intensive & Intensive & & \\
\hline & & Posterior arm & & & \\
\hline $1 / 2$ Dorper + 1/2 Santa Inês & 2.06 & 2.06 & 1.96 & $2.03 \mathrm{~B}$ & 0.07 \\
\hline 1⁄2 Texel + 1/2 Santa Inês & 2.18 & 2.08 & 2.00 & 2.09AB & 0.07 \\
\hline Pure Santa Inês & 2.34 & 2.39 & 2.04 & $2.26 \mathrm{~A}$ & 0.06 \\
\hline \multirow[t]{2}{*}{ Mean } & $2.19 \mathrm{a}$ & $2.17 \mathrm{a}$ & $2.00 \mathrm{a}$ & 2.13 & \\
\hline & & Anterior arm & & & \\
\hline $1 / 2$ Dorper $+1 / 2$ Santa Inês & 1.72 & 1.74 & 1.54 & $1.67 \mathrm{~A}$ & 0.06 \\
\hline $1 / 2$ Texel $+1 / 2$ Santa Inês & 1.60 & 1.64 & 1.37 & $1.54 \mathrm{~A}$ & 0.06 \\
\hline Pure Santa Inês & 1.83 & 1.70 & 1.64 & $1.73 \mathrm{~A}$ & 0.05 \\
\hline \multirow[t]{2}{*}{ Mean } & $1.72 \mathrm{a}$ & $1.69 \mathrm{a}$ & $1.52 b$ & 1.65 & \\
\hline & & Shoulder & & & \\
\hline $1 / 2$ Dorper $+1 / 2$ Santa Inês & 7.90 & 7.12 & 7.60 & $7.54 \mathrm{~A}$ & 0.17 \\
\hline $1 / 2$ Texel $+1 / 2$ Santa Inês & 7.56 & 7.80 & 7.80 & $7.72 \mathrm{~A}$ & 0.17 \\
\hline Pure Santa Inês & 7.77 & 7.36 & 7.36 & $7.50 \mathrm{~A}$ & 0.16 \\
\hline \multirow[t]{2}{*}{ Mean } & $7.74 \mathrm{a}$ & $7.43 \mathrm{a}$ & $7.59 a$ & 7.59 & \\
\hline & & Leg & & & \\
\hline $1 / 2$ Dorper $+1 / 2$ Santa Inês & 14.09 & 13.90 & 13.45 & $13.82 \mathrm{~A}$ & 0.18 \\
\hline $1 / 2$ Texel $+1 / 2$ Santa Inês & 14.10 & 13.49 & 13.68 & $13.76 \mathrm{~A}$ & 0.18 \\
\hline Pure Santa Inês & 13.84 & 13.62 & 13.43 & $13.63 \mathrm{~A}$ & 0.17 \\
\hline \multirow[t]{2}{*}{ Mean } & $14.01 \mathrm{a}$ & $13.67 a$ & $13.52 \mathrm{a}$ & 13.73 & \\
\hline & & Loin & & & \\
\hline $1 / 2$ Dorper $+1 / 2$ Santa Inês & 3.39 & 3.07 & 3.49 & $3.32 \mathrm{~A}$ & 0.11 \\
\hline $1 / 2$ Texel + 1/2 Santa Inês & 3.12 & 3.50 & 3.61 & $3.41 \mathrm{~A}$ & 0.11 \\
\hline Pure Santa Inês & 3.49 & 3.22 & 3.64 & $3.45 \mathrm{~A}$ & 0.10 \\
\hline \multirow[t]{2}{*}{ Mean } & $3.33 a$ & $3.26 a$ & $3.58 \mathrm{a}$ & 3.40 & \\
\hline & & Carré & & & \\
\hline $1 / 2$ Dorper $+1 / 2$ Santa Inês & 6.20 & 6.76 & 7.22 & $6.73 \mathrm{~B}$ & 0.23 \\
\hline $1 / 2$ Texel $+1 / 2$ Santa Inês & 7.73 & 7.48 & 7.37 & $7.52 \mathrm{~A}$ & 0.23 \\
\hline Pure Santa Inês & 7.62 & 7.12 & 7.93 & $7.56 \mathrm{~A}$ & 0.22 \\
\hline \multirow[t]{2}{*}{ Mean } & $7.18 \mathrm{a}$ & $7.12 \mathrm{a}$ & $7.51 \mathrm{a}$ & 7.26 & \\
\hline & & Rib/belly & & & \\
\hline $1 / 2$ Dorper $+1 / 2$ Santa Inês & 7.64 & 8.77 & 9.24 & $8.55 \mathrm{~A}$ & 0.37 \\
\hline $1 / 2$ Texel $+1 / 2$ Santa Inês & 8.72 & 8.02 & 8.94 & $8.56 \mathrm{~A}$ & 0.37 \\
\hline Pure Santa Inês & 8.61 & 8.28 & 9.28 & $8.73 \mathrm{~A}$ & 0.35 \\
\hline \multirow[t]{2}{*}{ Mean } & $8.32 \mathrm{a}$ & $8.36 a$ & $9.16 \mathrm{a}$ & 8.59 & \\
\hline & & Neck & & & \\
\hline $1 / 2$ Dorper $+1 / 2$ Santa Inês & $8.56 \mathrm{aAB}$ & 7.97aA & $8.34 \mathrm{aA}$ & $8.29 \mathrm{~A}$ & 0.49 \\
\hline $1 / 2$ Texel $+1 / 2$ Santa Inês & $6.46 \mathrm{aB}$ & 7.70aA & $6.51 \mathrm{aA}$ & $6.89 \mathrm{~B}$ & 0.49 \\
\hline Pure Santa Inês & $10.02 \mathrm{aA}$ & 8.62abA & $6.97 \mathrm{bA}$ & $8.53 \mathrm{~A}$ & 0.46 \\
\hline Mean & $8.35 a$ & $8.10 \mathrm{a}$ & $7.27 \mathrm{a}$ & 7.90 & \\
\hline
\end{tabular}

Means followed by different letters, capital letter in line and small letters in columns, differ $(\mathrm{P}<0.05)$ by $t$ test.

${ }^{1}$ Standard mean error.

There was significant interaction $(\mathrm{P}<0.05)$ for the neck percentage (Table 7). The data showed that the lambs of Santa Inês reared in extensive system, presented neck percentage larger than the F1 Texel $\times$ Santa Inês animals and Dorper $\times$ Santa Inês. In other managements, that difference was not observed. According to FurushoGarcia et al. (2006), the neck of Santa Inês lambs grows in an equal angle fashion, in other words, it develops at similar rates to the development of the animal body therefore, Santa Inês lambs showed, in the present work, more percentually representative necks when managed under extensive system, because of a more advanced age to reach the slaughter weight. The F1 animals did not show any differences in the neck percentage among the managements studied here (Table 7). These results indicate that the neck of the Santa Inês lambs is a carcass cut which is easily influenced regarded to the adopted management system.

\section{Conclusions}

Santa Inês pure lambs have performance and carcass characteristics similar to crossed lambs Texel $\times$ Santa Inês and Dorper $\times$ Santa Inês when reared in intensive systems. The crossing of Santa Inês breed with Dorper provides 
posterior arm and carré in smaller proportions in the carcass. The intensive management provides heavier shoulder, rib/dipper, carré, loin and leg.

\section{References}

ALVES, K.S.; CARVALHO, F.F.R.; FERREIRA, M.A. et al. Níveis de energia em dietas para ovinos Santa Inês: características de carcaça e constituintes corporais. Revista Brasileira de Zootecnia, v.32, n.6, p.1927-1936, 2003 (supl. 2).

CARVALHO, S.; BROCHIER, M.A.; PIVATO, J. et al. Desempenho e avaliação econômica da alimentação de cordeiros confinados com dietas contendo diferentes relações volumoso:concentrado. Ciência Rural, v.37, n.5, p.1411-1417, 2007.

CARVALHO, S.; SILVA, M.F.; CERUTTI, R. et al. Desempenho e componentes do peso vivo de cordeiros submetidos a diferentes sistemas de alimentação. Ciência Rural, v.35, n.3, p.650-655, 2005.

FISHER, A.V.; BOER, H. The EAAP standard method of sheep carcass assessment. Carcass measurements and dissection procedures. Livestock Production Science, v.38, p.149-159, 1994.

FURUSHO-GARCIA, I.F.; PEREIRA, I.G. Manejo de cruzamento em ovinos para as condições de Brasil. In: SEMANA DE ZOOTECNIA DA UfVJM, 4., 2007, Diamantina. Anais... Diamantina, 2007. p.33-52.

FURUSHO-GARCIA, I.F.; PEREZ, J.R.O.; BONAGURIO, S. et al. Desempenho de cordeiros Santa Inês puros e cruzas Santa Inês com Ile de France e Bergamácia. Revista Brasileira de Zootecnia, v.33, n.6, p.1591-1603, 2004.

FURUSHO-GARCIA, I.F.; PEREZ, J.R.O.; BONAGURIO, S. et al. Estudo alométrico dos cortes de cordeiros Santa Inês puros e cruzas. Revista Brasileira de Zootecnia, v.35, n.4, p.1416-1422, 2006.

GEAY, Y. Live wight measurements. In: EEC SEMINAR ON CRITERIA AND METHODS FOR ASSESSMENT OF CARCASS AND MEAT CHARACTERISTICS IN BEEF PRODUCTION
EXPERIMENTS, 1975, Zeist. Proceedings... Zeist: 1975. p.35-42.

KOSGEY, I.S.; BAKER, R.L.; UDO, H.M.J. et al. Successes and failures of small ruminant breeding programs in the tropics: a review. Small Ruminant Research, v.61, n.1, p.13-28, 2006.

MEDEIROS, G.R.; CARVALHO, F.F.R.; FERREIRA, M.A. et al. Efeito dos níveis de concentrado sobre os componentes nãocarcaça de ovinos Morada Nova em confinamento. Revista Brasileira de Zootecnia, v.37, n.6, p.1063-1071, 2008.

NATIONAL RESEARCH COUNCIL - NRC. Nutrient requirements of small ruminants: sheep, goats, cervids, and new world camelids. Committee on the Nutrient Requirements of Small Ruminants and National Research Council. New York: National Academy Press, 2006. 362p.

SAINZ, R.D. Qualidade das carcaças e da carne ovina e caprina. In: REUNIÃO ANUAL DA SOCIEDADE BRASILEIRA DE ZOOTECNIA, 33., 1996, Fortaleza. Anais... Fortaleza: Sociedade Brasileira de Zootecnia, 1996. p.3-14.

SHRESTHA, J.N.B.; FAHMY, M.H. Breeding goats for meat production: a review. 1. Genetic resources, management and breed evaluation. Small Ruminant Research, v.58, n.2, p.93-106, 2005.

SILVA SOBRINHO, A.G. Aspectos quantitativos e qualitativos da produção de carne ovina. A produção animal na visão dos brasileiros. In: REUNIÃO ANUAL DA SOCIEDADE BRASILEIRA DE ZOOTECNIA, 38., 2001, Piracicaba. Anais... Piracicaba: Sociedade Brasileira de Zootecnia, 2001. (CD-ROM).

STATISTICS ANALYSES SYSTEM - SAS. User's guide: statistics. Cary, 1991. 956p.

URANO, F.S.; PIRES, A.V.; SUSIN, I. et al. Desempenho e características da carcaça de cordeiros confinados alimentados com grãos de soja. Pesquisa Agropecuária Brasileira, v.41, n.10, p.1525-1530, 2006.

VILLARROEL, A.B.S.; LIMA, L.E.S.; OLIVEIRA, S.M.P. et al. Ganho de peso e rendimento de carcaça de cordeiros mestiços Texel e Santa Inês $\times$ SRD em sistema de manejo semi-intensivo. Ciência Agrotécnica, v.30, n.5, p.971-976, 2006.

YAMAMOTO, S.M.; MACEDO, F.A.F; ZUNDT, M. et al. Fontes de óleo vegetal na dieta de cordeiros em confinamento. Revista Brasileira de Zootecnia, v.34, n.2, p.703-710, 2005. 